\title{
EVALUASI PROGRAM PENGENTASAN KEMISKINAN \\ (Studi Kasus Pemberdayaan Ekonomi pada Program Nasional Pemberdayaan Masyarakat (PNPM) Mandiri Perkotaan di Kelurahan Perwira Kecamatan Bekasi Utara Kota Bekasi Jawa Barat)
}

\section{Ari Saptono*}

\begin{abstract}
This research is to evaluate the process of economy empowerment on PNPM Mandiri Perkotaan in Officer North Bekasi with targeted research that examines the implementation of economic development programs related to community participation, community capacity building, as well as assessing the degree of empowerment community. Model of evaluation which is used in this research is CIPP evaluation. In general, this evaluation model consists of four evaluation objectives, namely: Context Evaluation, Input Evaluation, Process Evaluation, Product evaluation. Research results showed: there is no standard criteria or indicators to determine the receivers of loan; achievement rate in providing infrastructure BKM is $42.85 \%$, it's in moderate category; staffing is in accordance with the procedures set out in the guidelines; public institutions is fully established. People's understanding of revolving loans varies. Public participation has achieve minimum target of $40 \%$. The quantity of training which can improve skill must be increased since skills owned by the members are expected can increase family income through home businesses. Perwira District has not develop partnership yet with external party such as: bank, corporate, and higher education institution. This economy empowerment program has satisfactory result, indicated by: 93\% of repayment rate, 2,63\% of loans at risk, $211,36 \%$ cost coverage ratio, and 6,54\% return on investment. Keywords: evaluate, economy, empowerment, PNPM
\end{abstract}

PENDAHULUAN

Kemiskinan merupakan permasalahan yang komplek yang

\footnotetext{
* Ari Saptono adalah dosen Fakultas Ekonomi Universitas Negeri Jakarta
}

membutuhkan perhatian semua pihak. Oleh karena itu dibutuhkan sebuah program yang mampu menggerakan masyarakat untuk mengatasi masalah kemiskinan. 


Salah satu upaya yang
dilakukan
mengatasi masalah kemiskinan di
perkotaan adalah melalui Program
Nasional Pemberdayaan Masyarakat
Mandiri Perkotaan (PNPM Mandiri
Perkotaan), yang awalnya
merupakan Program Penanggu-
langan Kemiskinan di Perkotaan
(P2KP) yang dilaksanakan sejak
tahun 1999. Program Penanggulangan Kemiskinan di Perkotaan (P2KP) merupakan salah satu bentuk upaya pemerintah untuk membangun kemandirian masyarakat dalam mengatasi kemiskinan secara berkesinambungan.

Dalam Pedoman Pelaksanaan PNPM Mandiri Perkotaan, dijelaskan bahwa sejak tahun 2007 keberlanjutan pelaksanaan P2KP diperluas lagi menjadi Program Nasional Pemberdayaan Masyarakat Mandiri Perkotaan (PNPM Mandiri Perkotaan), yang dilaksanakan untuk mendukung upaya pemerintah dalam menurunkan jumlah orang miskin di Indonesia dan diharapkan mampu meningkatkan kesejahteraan masyarakat Indonesia sesuai amanat UUD'45. Strategi Program Nasional Pemberdayan Masyarakat (PNPM) Mandiri Perkotaan dalam penanggulangan kemiskinan dilakukan melalui penguatan kelembagaan masyarakat. Kelembagaan masyarakat tersebut bertujuan menciptakan kemandirian dan keberlanjutan kemampuan menyampaikan aspirasi serta kebutuhan berkaitan dengan kebijakan publik di tingkat lokal, baik aspek sosial, ekonomi maupun lingkungan, termasuk perumahan dan pemukiman. Program penanggulangan kemiskinan dalam PNPM Mandiri, berbentuk bantuan langsung pada masyarakat untuk dapat lepas dari kemiskinan.

Kemiskinan masih menjadi masalah yang dihadapi masyarakat, berdasarkan data BPS jumlah penduduk miskin di Indonesia pada Maret 2012 masih mencapai 29,13 juta orang, yaitu 11,96 persen dari total penduduk Indonesia. Dari total penduduk miskin, 10,65 juta di daerah perkotaan (8,78 persen) sedangkan jumlah penduduk miskin di daerah pedesaan sebesar 18,48 juta (15,12 persen). Adapun jumlah penduduk miskin di Jawa Barat pada bulan Maret 2012 sebanyak 4.477.530 orang, yaitu 10,09 \% dari total jumlah penduduk.

Selanjutnya di Kota Bekasi jumlah penduduk miskin pada Maret Tahun 2012 sebanyak 34.274 orang, dengan rincian seperti dalam tabel berikut: 
Ari Saptono: Evaluasi Program Pengentasan Kemiskinan (Studi Kasus Pemberdayaan Ekonomi pada PNPM Mandiri Perkotaan di Kelurahan Perwira Kecamatan Bekasi Utara Kota Bekasi Jawa Barat

Tabel 1. Data Status Kesejahteraan Individu Kota Bekasi Per Maret 2012

\begin{tabular}{|c|l|r|r|r|r|}
\hline No. & $\begin{array}{c}\text { Nama } \\
\text { Kecamatan }\end{array}$ & $\begin{array}{c}\text { Kelompok 1 } \\
\text { (paling } \\
\text { miskin) }\end{array}$ & $\begin{array}{c}\text { Kelompok 2 } \\
\text { (Miskin) }\end{array}$ & $\begin{array}{c}\text { Kelompok 3 } \\
\text { (Rentan } \\
\text { Miskin) }\end{array}$ & TOTAL \\
\hline 1 & PONDOKGEDE & 15093 & 12561 & 10863 & 38517 \\
\hline 2 & JATISAMPURNA & 7128 & 3998 & 3380 & 14506 \\
\hline 3 & PONDOKMELATI & 7906 & 7599 & 7311 & 22816 \\
\hline 4 & JATIASIH & 16604 & 12030 & 8707 & 37341 \\
\hline 5 & BANTARGEBANG & 6506 & 5025 & 4505 & 16036 \\
\hline 6 & MUSTIKAJAYA & 10892 & 9894 & 8169 & 28955 \\
\hline 7 & BEKASI TIMUR & 12402 & 9446 & 8407 & 30255 \\
\hline 8 & RAWALUMBU & 11575 & 8384 & 7131 & 27090 \\
\hline 9 & BEKASI SELATAN & 8759 & 8752 & 8399 & 25910 \\
\hline 10 & BEKASI BARAT & 15033 & 12753 & 13366 & 41152 \\
\hline 11 & MEDAN SATRIA & 7995 & 7570 & 6745 & 22310 \\
\hline 12 & BEKASI UTARA & 11537 & 12047 & 13802 & 37386 \\
\hline & Jumlah & $\mathbf{1 3 1 . 4 3 0}$ & $\mathbf{1 1 0 . 0 5 9}$ & $\mathbf{1 0 0 . 7 8 5}$ & $\mathbf{3 4 2 . 2 7 4}$ \\
\hline
\end{tabular}

Sumber: Bappeda Kota Bekasi

Penelitian ini adalah untuk mengevaluasi proses pemberdayaan ekonomi masyarakat pada kegiatan PNPM Mandiri Perkotaan di Kelurahan Perwira Kecamatan Bekasi Utara Kota Bekasi dengan sasaran penelitian yaitu mengkaji implementasi program pemberdayaan ekonomi kaitannya dengan partisipasi masyarakat, pengembangan kapasitas masyarakat, serta mengkaji derajat keberdayaan masyarakat.

Untuk melihat efektititas Program Nasional Pemberdayaan Masyarakat (PNPM) Mandiri Perkotaan dalam penanggulangan kemiskinan perlu diadakan evaluasi yang merupakan instrumen pengelolaan kebijakan publik yang sangat kuat untuk membantu pengambil keputusan dan pelaksana melihat kemajuan dan dampak proyek, program, atau kebijakan PNPM Mandiri. Evaluasi dalam penelitian ini, berbasis pada konteks, masukan, proses, hasil/ keluaran, juga menekankan pada dampak (impact).

Model evaluasi program yang digunakan dalam evaluasi ini adalah CIPP Evaluation Model cara garis besar, model evaluasi ini terdiri dari empat sasaran evaluasi, yaitu: 
Context Evaluation, Input Evaluation, Process Evaluation, Product evaluation.

Tujuan umum PNPM telah ditetapkan di Pedoman Umum PNPM yaitu meningkatnya kesejahteraan dan kesempatan kerja masyarakat miskin secara mandiri. Dalam Penelitian ini dibatasi pada masalah bagaimana evaluasi terhadap pemberdayaan ekonomi masyarakat dalam program PNPM Mandiri Perkotaan dilihat dari aspek-aspek konteks, input, proses, dan produk. Adapun fokus penelitian evaluatif ini adalah Pemberdayaan Ekonomi Masyarakat pada Program Nasional Pemberdayaan Masyarakat Mandiri Perkotaan (PNPM MP).

\section{KAJIAN PUSTAKA}

\section{Pengertian Evaluasi Program}

Sasaran evaluasi program sangat beragam, dengan demikian akan memperngaruhi jenis dan model evaluasi yang akan digunakan. Definisi evaluasi program dikemukakan oleh Tyler, yang dikutip Suharsimi Arikunto (2010:4), bahwa evaluasi program adalah proses untuk mengetahui apakah tujuan pendidikan sudah dapat terealisasikan. Selanjutnya menurut S. Eko Putro Widoyoko (2011:10) evaluasi program merupakan rangkaian kegiatan yang dilakukan dengan sengaja dan cermat untuk mengetahui tingkat keterlaksanaan atau keberhasilan suatu program dengan cara mengetahui efektivitas masingmasing komponennya, baik pada program yang sedang berjalan maupun program yang sudah berlalu.

Selanjutnya menurut Owen (1993:7-8), evaluasi program adalah suatu proses menguraikan, menjabarkan informasi dan mendesiminasikannya untuk menjelaskan dan memahami suatu program atau menjustifikasi, menetapkan keputusan berkaitan dengan program tersebut.

Berdasarkan

beberapa pengertian evaluasi program di atas dapat disimpulkan bahwa evaluasi program adalah kegiatan sistematis untuk mengetahui keterlaksanaan dan tingkat keberhasilan suatu program dengan cara menganalisis efektivitas masing-masing komponen sebagai masukan untuk pengambilan keputusan terhadap suatu program.

Pemilihan model evaluasi yang akan digunakan dalam kegiatan penelitian evaluasi ditentukan berdasarkan konteks, input, proses dan produk. Model evaluasi ini dikembangkan oleh Stufflebeam pada 1965 sebagai hasil usahanya mengevaluasi ESEA (The Elementary and Secondary 
Education Act). Model yang ditawarkan Stufflebeam yang dikutip S. Eko Putro Widoyoko (2011:181), tujuan utamanya adalah bukan membuktikan tetapi untuk memperbaiki.

Model evaluasi program yang digunakan dalam evaluasi ini adalah CIPP Evaluation Model cara garis besar, model evaluasi ini terdiri dari empat sasaran evaluasi, yaitu: Context Evaluation, Input Evaluation, Process Evaluation, Product evaluation.

\section{Kemiskinan}

Kemiskinan merupakan
masalah sosial yang senantiasa
hadir di tengah-tengah masyarakat,
khususnyar negara-negara
berkembang. Menurut Mudrajad
Kuncoro (2000:103), kemiskinan
sebagai ketidakmampuan untuk
memenuhi standar hidup minimum. Sedangkan menurut E.J. Habsbown yang dikutip Jafar Hafsah (2008:10), kemiskinan tidak hanya diartikan dengan kemiskinan itu sendiri tetapi dapat digambarkan menurut yang terjadi dalam masyarakat. Dengan demikian kemiskinan bukan hanya ketiadaan harta benda dan pekerjaan melainkan lebih jauh dari itu, kemiskinan dapat terjadi karena alam lingkungan tidak sehat.
Selanjutnya menurut Edi Suharto (2010:132), kemiskinan merupakan konsep dan fenomena yang bermakna multidimensional. Kemiskinan memiliki beberapa ciri: ketidakmampuan memenuhi kebutuhan konsumsi dasar; ketiadaan akses terhadap kebutuhan dasar lainnya; ketiadaan jaminan masa depan; kerentanan terhadap goncangan yang bersifat individu dan masal; rendahnya kualitas SDM dan keterbatasan sumber daya alam; ketidakterlibatan dalam kegiatan sosial masyarakat; ketiadaan akses terhadap lapangan kerja dan mata pencaharian yang berkesinambungan;

ketidakmampuan untuk berusaha karena cacat fisik atau mental; ketidakmampuan dan ketidakberuntungan sosial.

Dengan demikian Kemiskinan merupakan masalah multidimensi, tidak hanya masalah pendapatan atau aspek ekonomi, tetapi masalah lingkungan yang tidak sehat, keterbatasan akses pada aset produktif, ketidakterlibatan dalam kegiatan sosial dan sebagainya.

Menurut World Bank yang dikutip Dawam Rahardjo (2006:12), penduduk yang dapat dikatakan miskin adalah yang pendapatannya di bawah US\$ 1 per hari dan kemiskinan menengah untuk pendapatan di bawah US\$ 2 per 
hari. Selanjutnya menurut World Bank yang dikutip Prima Sumarga (2001:35), kemiskinan adalah : The denial of choice and opportunities most basic for human development to lead a long healthy, creative life and enjoy a decent standard of living freedom, self esteem and the respect of other.

Dari beberapa definisi dan pendekatan kemiskinan, dapat dijelaskan bahwa kemiskinan dapat dilihat dari berbagai aspek, yaitu ekonomi, sosial, budaya, politik dan lingkungan. Hal ini sesuai dengan pengkategorian Badan Pusat Statistik (BPS), yang membagi kemiskinan dengan standar garis kemiskinan (poverty line) makanan dan non makanan. Garis kemiskinan makanan yaitu nilai pengeluaran konsumsi kebutuhan dasar makanan setara dengan 2100 kalori per kapita per hari. Garis kemiskinan non makanan adalah besarnya rupiah untuk memenuhi kebutuhan minimum non makanan seperti perumahan, kesehatan, pendidikan, angkutan, pakaian dan barang / jasa lainnya. Garis kemiskinan ini memiliki kesamaan dengan garis kemiskinan menurut Bank Dunia yaitu diukur menurut pendapatan seseorang.

Di bawah ini 14 indikator kemiskinan menurut BPS, sebagai dasar bagi keluarga yang berhak mendapatkan menerima Jamkesmas, Raskin, hingga Jamkesda, Bantuan Langsung Tunai (BLT). Keluarga yang berhak mendapatkan Bantuan Langsung Masyarakat (BLM) pada program pemberdayaan ekonomi PNPM Mandiri Perkotaan, apabila memenuhi 4 dari 14 kriteria.

Penyebab kemiskinan menurut Mudrajad Kuncoro (2000:107) sebagai berikut: pertama, secara mikro, kemiskinan muncul karena adanya ketidaksamaan pola kepemilikan sumber daya yang menimbulkan distribusi pendapatan timpang, penduduk miskin hanya memiliki sumber daya dalam jumlah yang terbatas dan kualitasnya rendah; Kedua, Kemiskinan muncul akibat perbedaan kualitas sumber daya manusia dimana kualitas sumber daya manusia yang rendah berarti produktivitas juga rendah, upahnya pun rendah; ketiga, Kemiskinan muncul disebabkan perbedaan akses dalam modal.

Penyebab kemiskinan tersebut bermuara pada teori lingkaran setan kemiskinan (vicious circle poverty) yang dikemukakan oleh Ragnar Nurkse yang dikutip Mudrajad Kuncoro (2000:107). Lingkaran setan kemiskinan digambarkan sebagai berikut: 


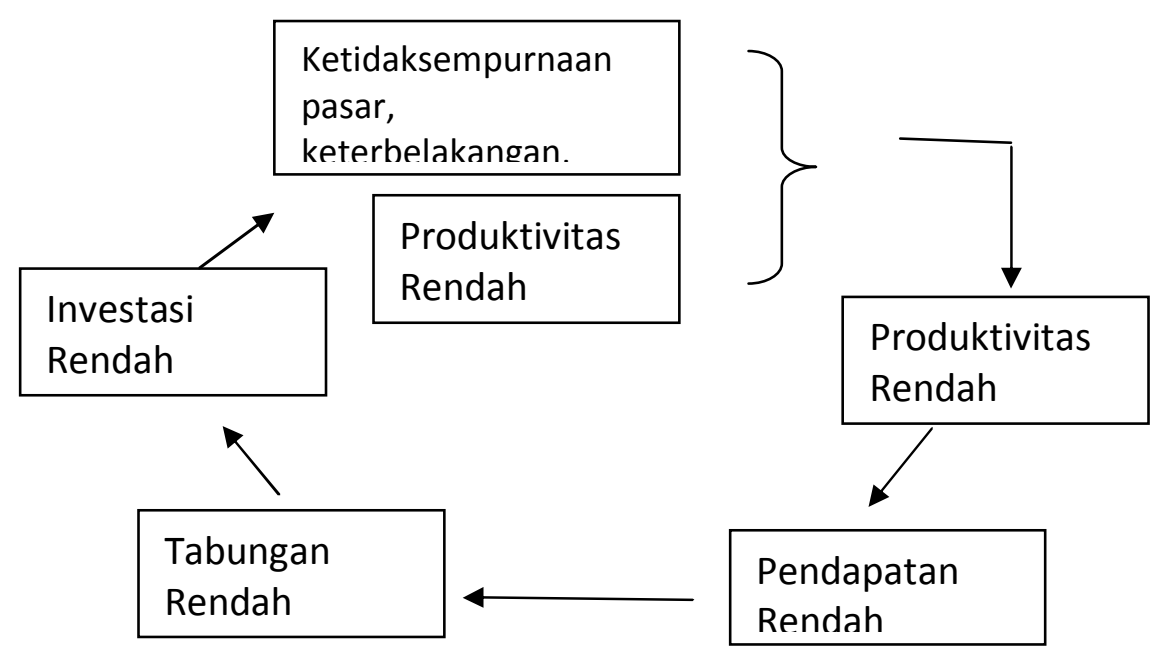

Gambar 1. Lingkaran Setan Kemiskinan (The Vicious Circle of Poverty)

Banyak faktor penyebab kemiskinan, tetapi dari berbagai faktor tersebut mana yang merupakan penyebab sebenarnya atau utama, atau faktor-faktor mana yang berpengaruh langsung dan tidak langsung terhadap perubahan kemiskinan. Jika diuraikan satu persatu, jumlah faktor-faktor yang dapat mempengaruhi tingkat kemiskinan cukup banyak. Menurut Edi Suharto (2010:18), secara konseptual penyebab kemiskinan diakibatkan oleh empat faktor, yaitu faktor individual, faktor sosial, faktor kultural, dan faktor struktural. Penanggulangan kemiskinan menurut Edi Suharto (2010:132) dapat dilakukan melalui dua pendekatan sosial. Pendekatan pertama melihat penyebab dan sumber-sumber penyelesaian kemiskinan dalam kaitannya dengan lingkungan tempat tinggal, baik konteks keluarga, kelompok atau masyarakat. Penanganan kemiskinan yang bersifat kelembagaan biasanya didasari oleh pertimbangan ini. Pendekatan kedua melihat si miskin dalam konteks situasinya, strategi pekerjaan sosial yang berpijak pada prinsip-prinsip individualisation dan self determinism. Program anti kemiskinan dalam kacamata ini disesuaikan dengan kejadian atau masalah yang dihadapinya. Beberapa bentuk program penanganan kemiskinan yang didasari dua pendekatan ini antara lain: pemberian bantuan sosial dan rehabilitasi sosial; program jaminan, perlindungan dan asuransi kesejahteraan sosial; program 
pemberdayaan

masyarakat, meliputi: pemberian modal usaha, pelatihan usaha produktif, pembentukan pasar sosial dan koperasi; program kedaruratan, misalnya bantuan uang, barang dan tenaga bagi korban bencana alam; program penanganan bagian yang hilang.

\section{Pemberdayaan Masyarakat}

Menurut I Nyoman Sumaryadi (2005:84), Otonomi meletakkan landasan pembangunan yang tumbuh dan berkembang dari rakyat, diselenggarakan secara sadar dan mandiri oleh rakyat, sehingga dalam program pembangunan masyarakat tidak lagi dianggap sebagai objek dari pembangunan, tetapi menjadi subjek/pelaku dari pembangunan. Dengan demikian masyarakat merasa ikut memiliki program tersebut dan mempunyai tanggung jawab atas keberhasilan sebuah program dan memiliki motivasi untuk berpartisipasi pada tahap selanjutnya. Melalui pemberdayaan, masyarakat akan lebih bertanggung jawab atas keberhasilan sebuah program.

Selanjutnya menurut Ife yang dikutip Suharto (2010:59), pemberdayaan mengandung makna kekuasaan atas: pilihan-pilihan personal dan kesempatan- kesempatan hidup: kemampuan membuat keputusan mengenai gaya hidup, tempat tinggal, pekerjaan; pendefinisian kebutuhan: kemampuan menentukan kebutuhan sesuai dengan aspirasi dan keinginannya; ide atau gagasan: kemampuan menyumbangakan ide atau gagasan dalam suatu forum secara bebas tanpa tekanan; lembaga-lembaga: kemampuan menjangkau, menggunakan dan mempengaruhi pranata-pranata masyarakat, seperti lembaga kesejahteraan sosial, pendidikan kesehatan; sumber-sumber: kemampuan memobilisasi sumbersumber formal, informal dan masyarakat; aktivitas ekonomi: kemampuan memanfaatkan dan mengelola mekanisme produksi, distribusi, dan pertukaran barang serta jasa; reproduksi: kemampuan dalam kaitannya dengan proses kelahiran, perawatan anak, pendidikan dan sosialisasi.

Hal ini sesuai dengan pendapat Sumaryadi (2005:105) bahwa memberdayakan orang lain pada hakikatnya merupakan perubahan budaya, sehingga pemberdayaan tidak akan jalan jika tidak dilakukan perubahan seluruh budaya organisasi secara mendasar. Perubahan budaya sangat diperlukan untuk mampu mendukung upaya sikap dan praktik 
bagi pemberdayaan yang lebih efektif.

Dengan demikian pemberdayaan merupakan serangkaian kegiatan untuk memperkuat kekuasaan bagi kelompok lemah termasuk individu yang menghadapi masalah kemisikinan baik secara fisik, ekonomi dan sosial. Pemberdayaan masyarakat berarti juga dimaknai sebagai upaya untuk memberikan kekuasaan agar pada kegiatan perencanaan dan pengambilan keputusan, mendengarkan pendapat masyarakat. Dengan adanya pemberdayaan, diharapkan masyarakat memiliki budaya yang proaktif untuk kemajuan bersama, mengenal diri dan lingkungannya serta memiliki sikap bertanggung jawab dan memposisikan dirinya sebagai subjek dalam upaya pembangunan di lingkungannya.

Rubin yang dikutip Sumaryadi (2005:94) mengemukakan lima prinsip dasar konsep pemberdayaan masyarakat, yaitu sebagai berikut: pertama, Pemberdayaan masyarakat memerlukan break-even dalam setiap kegiatan yang dikelolanya, meskipun orientasinya berbeda dari organisasi bisnis, dimana dalam pemberdayaan masyarakat keuntungan yang diperoleh didistribusikan kembali dalam bentuk program atau kegiatan pembangunan lainnya. Kedua, Pemberdayaan masyarakat selalu melibatkan partisipasi masyarakat baik dalam perencanaan maupun pelaksanaan yang dilakukan. Ketiga, pelaksanaan program pemberdayaan masyarakat, kegiatan pelatihan merupakan unsur yang tidak bisa dipisahkan dari usaha pembangunan fisik. Keempat, dalam implementasinya, usaha pemberdayaan harus dapat memaksimalkan sumber daya, khususnya dalam hal pembiayaan baik yang berasal dari pemerintah, swasta maupun sumber-sumber lainnya. Kelima, Kegiatan pemberdayaan masyarakat harus dapat berfungsi sebagai penghubung antara kepentingan pemerintah yang bersifat makro dengan kepentingan masyarakat yang bersifat mikro.

Proses pemberdayaan umumnya dilakukan secara kolektif (Parson et.al. dalam Suharto) (2010:66) walaupun pada beberapa situasi pemberdayaan dapat saja dilakukan secara individual. Pada konteks pekerjaan sosial, proses pemberdayaan dapat dilakukan melalui tiga aras, yaitu:

1. Aras mikro, pemberdayaan dilakukan terhadap klien secara individu melalui bimbingan, konseling, stress management, dan crisis intervention. 
2. Aras mezzo, pemberdayaan dilakukan terhadap sekelompok individu melalui pendidikan dan pelatihan, serta dinamika kelompok guna meningkatkan kesadaran, pengetahuan, keterampialan agar memiliki kemampuan memecahkan permasalahan.

3. Aras makro, dimana pemberdayaan dilakukan dalam sistem lingkungan yang lebih luas melalui perumusan kebijakan, perencanaan sosial, kampanye, aksi sosial, pengorganisasian masyarakat, manajemen konflik dan sebagainya.

Jadi proses pemberdayaan bisa dimaknai sebagai runtutan perubahan dalam perkembangan usaha untuk membuat masyarakat menjadi lebih berdaya.

\section{PNPM Mandiri Perkotaan}

Tahun 2008 secara penuh P2KP menjadi Program Nasional Pemberdayaan Masyarakat Mandiri Perkotaan (PNPM Mandiri Perkotaan). Sebagai bagian dari PNPM Mandiri maka tujuan, prinsip dan pendekatan yang ditetapkan dalam PNPM Mandiri juga menjadi tujuan, prinsip dan pendekatan PNPM Mandiri Perkotaan, begitu juga nama generik lembaga kepemimpinan masyarakat berubah dari BKM menjadi LKM (Lembaga Keswadayaan Masyarakat). Dasar hukum pelaksanaan PNPM Mandiri Perkotaan adalah sama dan merujuk pada Dasar Hukum PNPM Mandiri, sebagaimana ditetapkan dalam Pedoman Umum PNPM Mandiri, Peraturan Presiden Nomor.13 Tahun 2009 tentang Koordinasi Penanggulangan Kemiskinan.

Visi kegiatan PNPM Mandiri Perkotaan adalah terciptanya masyarakat yang berdaya yang mampu menjalin sinergi dengan pemerintah daerah serta kelompok peduli setempat dalam rangka menanggulangi kemiskinan dengan efektif, secara mandiri dan berkelanjutan. Sedangkan misi kegiatan PNPM Mandiri Perkotaan adalah memberdayakan masyarakat perkotaan, terutama masyarakat miskin, untuk menjalin kerjasama sinergis dengan pemerintah daerah dan kelompok peduli lokal dalam upaya penanggulangan kemiskinan, melalui pengembangan kapasitas, penyediaan sumber daya, dan melembagakan budaya kemitraan antar pelaku pembangunan. Dari visi dan misi tersebut dapat kita pahami bahwa pengembangan kapasitas merupakan salah satu aspek dalam upaya pemberdayaan masyarakat untuk mencapai tujuan utama yaitu menanggulangi kemiskinan. 
Tujuan umum PNPM telah ditetapkan di Pedoman Umum PNPM yaitu Meningkatnya kesejahteraan dan kesempatan kerja masyarakat miskin secara mandiri". Dengan demikian secara khusus tujuan PNPM Mandiri Perkotaan dirumuskan sebagai berikut: "Masyarakat di kelurahan peserta program menikmati perbaikan sosial ekonomi dan tata kepemerintahan lokal". Selanjutnya sasaran dari Program PNPM Mandiri Perkotaan adalah

a. Terbangunnya

Lembaga Keswadayaan Masyarakat (LKM) yang dipercaya, aspiratif, representatif, dan akuntabel untuk mendorong tumbuh dan berkembangnya partisipasi serta kemandirian masyarakat;

b. Tersedianya Perencanaan Jangka Menengah (PJM) Pronangkis sebagai wadah untuk mewujudkan sinergi berbagai program penanggulangan kemiskinan yang komprehensif dan sesuai dengan aspirasi serta kebutuhan masyarakat dalam rangka pengembangan lingkungan permukiman yang sehat, serasi, berjati diri dan berkelanjutan;

c. Terbangunnya forum LKM tingkat kecamatan dan kota/ kabupaten untuk mengawal terwujudnya harmonisasi berbagai program daerah

d. Terwujudnya kontribusi pendanaan dari Pemerintah kota/ Kabupaten dalam PNPM Mandiri Perkotaan sesuai dengan kapasitas fiskal daerah.

Implemintasi PNPM Mandiri Perkotaan pada tingkat kelurahan diwadahi sebuah lembaga yaitu Badan atau Lembaga Keswadayaan Masyarakat atau disingkat BKM/LKM) dibentuk melalui kesadaran kritis masyarakat untuk menggali kembali nilai-nilai luhur kemanusiaan dan nilai-nilai kemasyarakatan sebagai pondasi modal sosial (capital social) kehidupan masyarakat.

BKM ini menjadi wadah bagi kaum miskin dalam menyuarakan aspirasi dan kebutuhan mereka, sekaligus menjadi motor bagi upaya penanggulangan kemiskinan yang dijalankan oleh masyarakat secara mandiri dan berkelanjutan, mulai dari proses penentuan kebutuhan, pengambilan keputusan, proses penyusunan program, pelaksanaan program hingga pemanfaatan dan pemeliharaan.

Penanggulangan kemiskinan membutuhkan penanganan yang menyeluruh dalam skala perwilayahan yang memadai yang memungkinkan terjadinya keterpaduan antara pendekatan sektoral, 
perwilayah dan partisipatif yang dalam hal ini dipilih kecamatan sebagai lokus program yang mampu mempertemukan perencanaan dari atas dan dari bawah. Di tataran kecamatan inilah rencana pembangunan yang direncanakan oleh SKPD (Satuan Kerja Perangkat Daerah) bertemu dengan perencanaan dari masyarakat dalam Musrenbang (Musyawarah Perencanaan Pembangunan) Kecamatan sehingga dapat digalang perencanaan pembangunan yang menyeluruh, terpadu dan selaras waktu (synchrone). Dengan demikian PNPM Mandiri Perkotaan akan menekankan pemanfaatan Musrenbang Kecamatan sebagai mekanisme harmonisasi kegiatan berbagai program yang ada sehingga peranan Forum LKM tingkat kecamatan menjadi sangat vital.

Masing-masing BKM mewadahi Kelompok Swadaya Masyarakat (KSM), yang dibentuk di tingkat komunitas atau masyarakat untuk melakukan agenda kegiatan secara langsung. KSM ini dapat dibentuk oleh siapa saja atau kelompok masyarakat apabila diperlukan untuk melaksanakan suatu kegiatan tertentu yang dianggap perlu bagi pembangunan dalam komunitas tersebut. KSM ini diorganisasikan oleh tim relawan dan dibantu oleh tim fasilitator terdiri dari warga kelurahan yang memiliki ikatan kebersamaan (common bond) dan berjuang untuk mencapai tujuan bersama. KSM ini bukan hanya sekedar pemanfaat pasif melainkan sekaligus sebagai pelaksana kegiatan terkait dengan penangulangan kemiskinan yang diusulkan untuk didanai oleh LKM melalui berbagai dana yang mampu digalang.

Dengan demikian Pemberdayaan masyarakat pada PNPM Mandiri Perkotaan terutama dititikberatkan pada upaya penguatan pelakunya untuk mampu menjadi pelaku nilai dan pada gilirannya mampu menjadi motor penggerak dalam 'melembagakan' dan 'membudayakan' kembali nilainilai luhur universal kemanusiaan (gerakan moral), prinsip-prinsip kemasyarakatan (gerakan tatakepemerintahan yang baik) serta prinsipprinsip pembangunan berkelanjutan (gerakan Tridaya), sebagai nilai-nilai utama yang melandasi aktivitas penanggulangan kemiskinan oleh masyarakat setempat. Melalui lembaga kepemimpinan masyarakat tersebut diharapkan tidak ada lagi kelompok masyarakat yang masih terjebak dalam lingkaran kemiskinan, yang pada gilirannya diharapkan dapat tercipta lingkungan perkotaan dengan perumahan yang 
lebih layak huni di dalam permukiman yang lebih responsif dan dengan sistem sosial masyarakat yang lebih mandiri melaksanakan prinsip-prinsip pembangunan berkelanjutan.
Gambaran tentang cara pandang PNPM Mandiri Perkotaan dalam memfasilitasi upaya penanggulangan akar persoalan kemiskinan oleh masyarakat dapat dilihat pada Gambar 2.

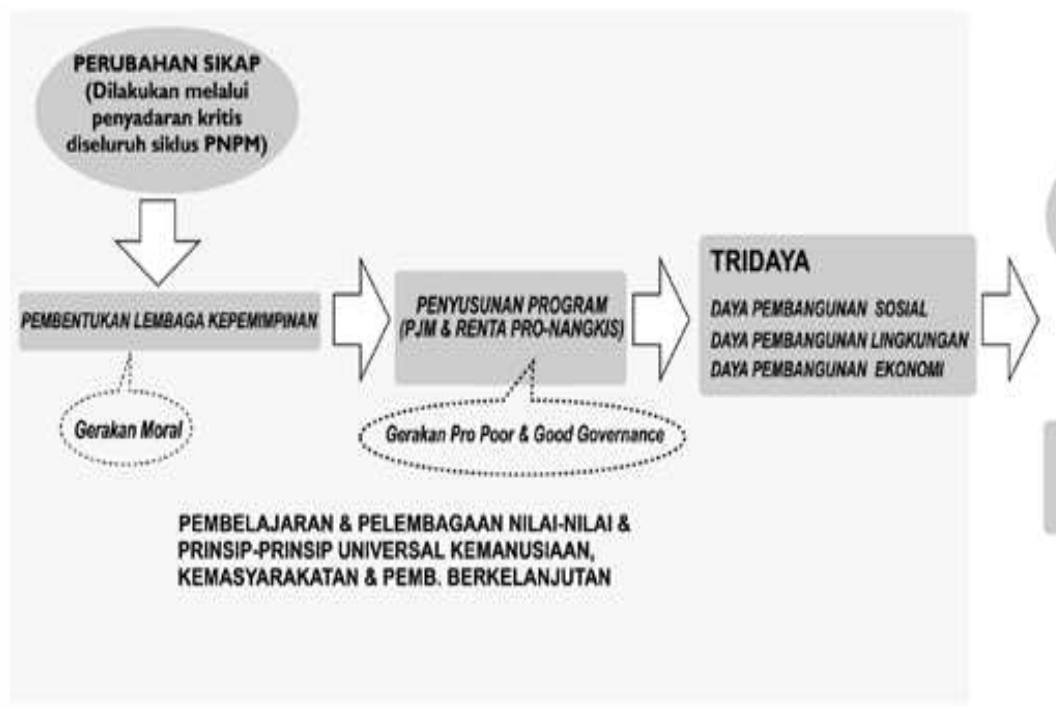

Penanogulangan Kemiskinan Secara Mandiri \& Berkelanjutan (Sustainable Development) dean Cun Kernitran Sinergis dan Channelling Program

Gambar 2. Diagram Penanganan Akar Kemiskinan oleh Masyarakat melalui PNPM Mandiri Perkotaan

$\begin{array}{lll}\text { Yang menjadi kelompok } & \text { Perkotaan dapat dilihat pada tabel } \\ \text { sasaran dalam PNPM Mandiri } & \text { berikut: }\end{array}$

\begin{tabular}{|l|l|l|}
\hline Uraian Kelompok Sasaran & Bantuan Teknik/ Pendampingan & Bantuan Dana BLM (Bantuan Langsung Masyarakat) \\
\hline Masyarakat & $\begin{array}{l}\text { - Masyarakat warga kelurahan peserta } \\
\text { PNPM Mandiri Perkotaan, } \\
\text { - LKM/Lembaga Keswadayaan Masyarakat, } \\
\text { - KSM/kelompok swadaya masyarakat. }\end{array}$ & $\begin{array}{l}\text { Warga kelurahan yg miskin menurut kriteria } \\
\text { kemiskinan setempat yang disepakati warga, } \\
\text { termasuk yang telah lama miskin, yang penghasilannya } \\
\text { menjadi tidak berarti karena inflasi, yang kehilangan } \\
\text { sumber penghasilannya. }\end{array}$ \\
\hline $\begin{array}{l}\text { Pemerintah Kota/Kabupaten, TKPP } \\
\text { dan TKPK Daerah }\end{array}$ & $\begin{array}{l}\text { Perangkat pemerintahan kota/kabupaten } \\
\text { s/d kelurahan/desa yang terkait dengan } \\
\text { pelaksanaan PNPM Mandiri Perkotaan, } \\
\text { anggota TKPP dan TKPK Daerah }\end{array}$ & \\
\hline Para Pemangku Kepentingan terkait & $\begin{array}{l}\text { Perorangan atau asosiasi profesi, asosiasi } \\
\text { usaha sejenis, perguruan tinggi, LSM, } \\
\text { Bank, notaris, auditor publik, media masa } \\
\text { (radio, tv, dsb) yang peduli dengan } \\
\text { kemiskinan, }\end{array}$ \\
\hline
\end{tabular}


Bantuan untuk masyarakat dalam kegiatan PNPM Mandiri Perkotaan diwujudkan dalam bentuk bantuan pendampingan dan bantuan dana.

a. Bantuan pendampingan ini diwujudkan dalam bentuk penugasan konsultan dan fasilitator beserta dukungan dana operasional untuk mendampingi dan memberdayakan masyarakat agar mampu merencanakan dan melaksanakan program masyarakat untuk menanggulangi kemiskinan di kelurahan masing-masing.

b. Bantuan dana diberikan dalam bentuk dana BLM (dana bantuan langsung masyarakat). Bantuan dana ini diberikan dalam bentuk Dana BLM (Bantuan Langsung Masyara- kat). BLM ini bersifat stimulan dan sengaja disediakan untuk memberi kesempatan kepada masyarakat untuk belajar dan berlatih dengan mencoba melaksanakan sebagian rencana kegiatan penanggulangan kemiskinan yang telah ditetapkan pada PJM dan Renta Pronangkis.

\section{Kriteria Keberhasilan}

Berlandaskan

acuan teoretik dan kerangka berpikir di atas, disusunlah kriteria keberhasilan evaluasi Program Pemberdayaan Ekonomi pada PNPM Mandiri Perkotaan dalam tabel berikut ini:

\section{Tabel 2. Kriteria Keberhasilan}

\begin{tabular}{|c|l|l|l|}
\hline Komponen & $\begin{array}{l}\text { Aspek yang } \\
\text { Dievaluasi }\end{array}$ & \multicolumn{1}{|c|}{ Indikator } & \multicolumn{1}{|c|}{ Kriteria Keberhasilan } \\
\hline \multirow{2}{*}{ Kebijakan } & $\begin{array}{l}\text { Merumuskan latar } \\
\text { belakang dan } \\
\text { mempunyai dasar } \\
\text { hukum }\end{array}$ & $\begin{array}{l}\text { Latar belakang dan dasar } \\
\text { PNPM Mandiri Perkotaan }\end{array}$ \\
\cline { 2 - 5 } & $\begin{array}{l}\text { Visi, misi, } \\
\text { Tujuan }\end{array}$ & Butir-butir tujuan & $\begin{array}{l}\text { Butir-butir visi, misi, tujuan } \\
\text { PNPM Mandiri Perkotaan }\end{array}$ \\
\cline { 2 - 5 } & $\begin{array}{l}\text { Kebutuhan } \\
\text { masyarakat }\end{array}$ & $\begin{array}{l}\text { Masyarakat } \\
\text { menyampaikan } \\
\text { kebutuhannya dalam }\end{array}$ & $\begin{array}{l}\text { Program pemberdayaan } \\
\text { ekonomi memenuhi kebutuhan } \\
\text { masyarakat dalam bidang }\end{array}$ \\
\hline
\end{tabular}


Ari Saptono: Evaluasi Program Pengentasan Kemiskinan (Studi Kasus Pemberdayaan Ekonomi pada PNPM Mandiri Perkotaan di Kelurahan Perwira Kecamatan Bekasi Utara Kota Bekasi Jawa Barat

\begin{tabular}{|c|c|c|c|}
\hline Komponen & $\begin{array}{c}\text { Aspek yang } \\
\text { Dievaluasi }\end{array}$ & Indikator & Kriteria Keberhasilan \\
\hline & & bidang ekonomi & $\begin{array}{l}\text { peningkatan pendapatan } \\
\text { masyarakat }\end{array}$ \\
\hline & Sasaran & $\begin{array}{l}\text { - Keluarga Miskin } \\
\text { - BKM dan KSM }\end{array}$ & $\begin{array}{ll}\text { - } & \text { Persentase Jumlah } \\
\text { Keluarga miskin yang } \\
\text { mendapatkan pinjaman } \\
\text { bergulir } \\
\text { - } \begin{array}{l}\text { Terbentuknya BKM dan } \\
\text { KSM }\end{array}\end{array}$ \\
\hline \multirow[t]{2}{*}{ Input } & $\begin{array}{l}\text { Sarana } \\
\text { prasarana } \\
\text { kerja }\end{array}$ & $\begin{array}{l}\text { sarana dan prasarana } \\
\text { kerja yang lengkap } \\
\text { dan dapat } \\
\text { dioperasikan bagi } \\
\text { pengelola }\end{array}$ & $\begin{array}{l}\text { Sarana dan prasarana kerja } \\
\text { pengelola sesuai dengan } \\
\text { kebutuhan kerja dan dapat } \\
\text { dioperasikan }\end{array}$ \\
\hline & $\begin{array}{l}\text { Sumber daya } \\
\text { pengelola }\end{array}$ & $\begin{array}{l}\text { - Pola Rekrutmen } \\
\text { - Terbentuknya } \\
\text { Lembaga } \\
\text { Masyarakat }\end{array}$ & $\begin{array}{ll}\text { - } & \text { Rekrutmen pengelola } \\
\text { dilakukan secara berjenjang } \\
\text { - } & \text { Terbentuknya lembaga } \\
& \text { masyarakat } 100 \%\end{array}$ \\
\hline
\end{tabular}

METODE PENELITIAN

\section{Tujuan Evaluasi}

Penelitian ini secara umum bertujuan untuk mendapatkan informasi dan mengevaluasi pemberdayaan ekonomi pada PNPM Mandiri Perkotaan di Kelurahan Perwira Kecamatan Bekasi Utara Kota Bekasi. Hasil evaluasi bagi Pemerintah Daerah dapat dijadikan dasar pengambilan keputusan apakah akan menghentikan, meneruskan, atau memperbaiki pelaksanaan pemberdayaan ekonomi pada Program PNPM Mandiri Perkotaan. Secara operasional tujuan evaluasi program adalah sebagai berikut:

1. Konteks

program pemberdayaan ekonomi pada PNPM Mandiri Perkotaan, yang meliputi kebijakan Pemerintah, tujuan, kebutuhan masyarakat dan sasaran

2. Input program pemberdayaan ekonomi pada PNPM Mandiri Perkotaan, yang berupa sarana prasarana kerja dan sumber daya pengelola

3. Proses program pemberdayaan ekonomi pada PNPM Mandiri Perkotaan, yang berupa 
perencanaan, pengembangan kapasitas, dan kinerja pengelola

4. Produk program pemberdayaan ekonomi pada PNPM Mandiri Perkotaan, yaitu manfaat ekonomi bagi masyarakat

\section{Tempat dan Waktu Evaluasi}

Penelitian ini dilaksanakan di Kelurahan Perwira Kecamatan Bekasi Utara Kota Bekasi Jawa Barat, pada bulan SeptemberOktober 2012.

\section{Metode Penelitian}

Penelitian ini menggunakan metode evaluasi. Menurut Suharsimi Arikunto (2010:7) metode evaluasi yaitu penelitian untuk mengetahui hasil akhir dari adanya kebijakan, dalam rangka menentukan rekomendasi atas kebijakan yang lalu, yang pada tujuan akhirnya dalah untuk menentukan kebijakan selanjutnya. Model evaluasi program yang digunakan dalam evaluasi ini adalah CIPP Evaluation Model cara garis besar, model evaluasi ini terdiri dari empat sasaran evaluasi, yaitu: Context Evaluation, Input Evaluation, Process Evaluation, Product evaluation.

\section{Teknik Pengumpulan Data}

Penelitian ini menggunakan teknik pengumpulan data menggunakan angket atau kuesioner. Selain memakai angket, penelitian ini juga memanfaatkan analisis dokumen dan wawancara. Data primer dalam penelitian ini diperoleh secara langsung dari dokumen-dokumen, pengelola dan pemerintah daerah. Instrumeninstrumen penelitian yang dipergunakan ialah angket atau kuesioner, dokumentasi, dan pedoman wawancara

\section{Teknik Analisis Data}

Teknik analisis data yang digunakan dalam penelitian ini adalah analisis deskriptif kuantitatif untuk data yang diperoleh dengan angket dan observasi, dan juga analisis kualitatif untuk data-data yang dikumpulkan dengan wawancara dan analisis dokumen. Analisis data deskriptif kuantitatif dengan statistika deskriptif bertujuan untuk melukiskan dan menganalisis kelompok data, tanpa membuat atau menarik kesimpulan atas objek-objek penelitian yang diamati.

\section{HASIL PENELITIAN DAN PEMBAHASAN \\ Deskripsi Program}

Tujuan PNPM Mandiri Perkotaan dirumuskan sebagai berikut: "Masyarakat di kelurahan peserta program menikmati perbaikan sosial ekonomi dan tata 
kepemerintahan lokal". Implemintasi PNPM Mandiri Perkotaan pada tingkat kelurahan diwadahi sebuah lembaga yaitu Badan atau Lembaga Keswadayaan Masyarakat atau disingkat BKM/LKM, dibentuk melalui kesadaran kritis masyarakat untuk menggali kembali nilai-nilai luhur kemanusiaan dan nilai-nilai kemasyarakatan sebagai pondasi modal sosial (capital social) kehidupan masyarakat.

Pemberdayaan masyarakat pada PNPM Mandiri Perkotaan terutama dititikberatkan pada upaya penguatan pelakunya untuk mampu menjadi pelaku nilai dan pada gilirannya mampu menjadi motor penggerak dalam 'melembagakan' dan 'membudayakan' kembali nilainilai luhur universal kemanusiaan (gerakan moral), prinsip-prinsip kemasyarakatan (gerakan tatakepemerintahan yang baik) serta prinsip-prinsip pembangunan berkelanjutan (gerakan Tridaya), sebagai nilai-nilai utama yang melandasi aktivitas penanggulangan kemiskinan oleh masyarakat setempat. Gerakan Tridaya meliputi pemberdayaan sosial, lingkungan dan ekonomi.

\section{Deskripsi dan Pembahasan Hasil Evaluasi}

$\begin{array}{crr} & \text { Deskripsi dan } & \text { pembahasan } \\ \text { hasil } & \text { evaluasi } & \text { Program }\end{array}$

Pemberdayaan Ekonomi pada Program PNPM Mandiri Perkotaan dan pengambilan keputusan berdasarkan indikator keberhasilan yang telah ditentukan, secara berturut-turut dari konteks, input, proses sampai produk.

\section{Konteks}

\section{a. Kebijakan}

Dasar hukum pelaksanaan PNPM Mandiri Perkotaan adalah sama dan merujuk pada Dasar Hukum PNPM Mandiri, sebagaimana ditetapkan dalam Pedoman Umum PNPM Mandiri, Peraturan Presiden Nomor: 13 Tahun 2009 tentang Koordinasi Penanggulangan Kemiskinan.

\section{b. Visi, Misi, dan Tujuan}

Visi kegiatan PNPM Mandiri Perkotaan adalah terciptanya masyarakat yang berdaya yang mampu menjalin sinergi dengan pemerintah daerah serta kelompok peduli setempat dalam rangka menanggulangi kemiskinan dengan efektif, secara mandiri dan berkelanjutan. Sedangkan misi kegiatan PNPM Mandiri Perkotaan adalah memberdayakan masyarakat perkotaan, terutama masyarakat miskin, untuk menjalin kerjasama sinergis dengan pemerintah daerah dan kelompok peduli lokal dalam upaya penanggulangan kemiskinan, melalui pengembangan kapasitas, 
penyediaan sumber daya, dan melembagakan budaya kemitraan antar pelaku pembangunan. Dari visi dan misi tersebut dapat kita pahami bahwa pengembangan kapasitas merupakan salah satu aspek dalam upaya pemberdayaan masyarakat untuk mencapai tujuan utama yaitu menanggulangi kemiskinan.

Tujuan umum PNPM telah ditetapkan di Pedoman Umum PNPM yaitu Meningkatnya kesejahteraan dan kesempatan kerja masyarakat miskin secara mandiri.

\section{c. Kebutuhan Masyarakat}

Penelitian ini hanya melihat kebutuhan dari sisi ekonomi, yaitu kebutuhan lapangan kerja dan permodalan untuk membuka dan mengembangkan usaha produktif. Hasil-hasil wawancara dengan Koordinator KSM Kelurahan Perwira menunjukkan bahwa masyarakat miskin mempunyai kebutuhankebutuhan dalam upaya untuk meningkatkan kesejahteraan mereka.

Program Pemberdayaan
Ekonomi pada PNPM Mandiri
Perkotaan dilakukan dengan
memberikan pinjaman bergulir
untuk kegiatan yang secara
langsung memberikan manfaat dan
peningkatan pendapatan bagi
individu/keluarga maupun kelompok

dan sekaligus mengembangkan modal sosial. Kegiatan yang dapat dibiayai dengan BLM antara lain usaha ekonomi produktif, pengembangan modal ekonomi keluarga yang bermanfaat langsung bagi peningkatan pendapatan keluarga miskin, usaha kelompok.

\section{d. Sasaran}

Jumlah keluarga miskin di Kelurahan Perwira Kecamatan Bekasi Utara yang mendapatkan pinjaman bergulir sebanyak $69 \mathrm{KSM}$ dengan jumlah anggota 249 orang. Dari jumlah tersebut yang mendapatkan pinjaman bergulir P2KP sebanyak $65 \mathrm{KSM}$ dengan jumlah anggota 218 orang dan sisanya 4 KSM dengan 31 orang anggota mendapatkan pinjaman bergulir dari PNPM Mandiri Perkotaan. Berdasarkan data dari BKM seluruh masyarakat miskin di Kelurahan Perwira mendapatkan pinjaman bergulir.

Berdasarkan hasil wawancara dengan Koordinator BKM, yang menentukan siapa berhak mendapatkan pinjaman bergulir adalah Ketua RT atau Ketua RW yang selanjutnya diadakan evaluasi oleh Koordinator BKM. Indikator yang dijadikan dasar dalam menentukan siapa berhak mendapatkan pinjaman bergulir adalah perkiraan dari tokoh 
masyarakat dengan hanya melihat pendapatan dibandingkan dengan jumlah tanggungan keluarga. Hal ini menunjukkan, bawah penentuan keluarga miskin tidak mengacu pada kriteria yang telah ditetapkan BPS. Menurut BPS terdapat 14 indikator dikategorikan keluarga miskin.

\section{Input}

\section{a. Sarana dan Prasarana Kerja} Pelayanan terhadap masyarakat salah satunya ditentukan sarana dan prasarana kerja. Sarana dan prasarana kerja merupakan salah bentuk pelayanan BKM terhadap masyarakat. Hasil angket untuk pengelola menunjukkan bahwa tingkat keberhasilan penyediaan sarana dan prasarana kerja BKM sebesar 42,85\%. Maka, disimpulkan bahwa keberhasilan penyediaan sarana dan prasarana kerja kepada pengelola BKM adalah mendekati kategori sedang. Berdasarkan hasil wawancara pengadaan sarana prasarana dilakukan secara mandiri oleh BKM.

\section{b. Sumber Daya Pengelola}

Sumber daya pengelola BKM dan KSM juga menentukan kualitas pelayanan terhadap anggota KSM. Indikator pengelola BKM dan KSM meliputi rekrutmen dan pemberdayaan akan menentukan keberhasilan pelayanan.

Berdasarkan hasil wawancara dengan pengelola BKM, rekrutmen pengelola dilakukan secara berjenjang. Pemilihan dimulai dari komunitas basis (RT, dukuh, dsb) dimana rekam jejak pelaku dikenali, utusan yang dipilih di tingkat RT kemudian dipilih ulang untuk menetapkan utusan di tingkat RW (apabila jumlah RT terlalu banyak) atau langsung dipilih ditingkat kelurahan apabila jumlah RT relatif sedikit. Dengan demikian pola rekrutmen pengelola BKM sudah sesuai dengan prosedur yang telah ditetapkan dalam pedoman pelaksanaan PNPM Mandiri Perkotaan.

Pengelola yang sudah dipilih mendapatkan pelatihan dasar dan lanjutan untuk mengenali berbagai persolan penyebab kemiskinan baik di tingkat kelurahan dan skala masyarakat (KSM), pelatihan lainnya adalah pemahaman pedoman PNPM MP dalam seluruh tahapan kegiatan pelaksanaan PNPM MP. Sasaran selanjutnya dalam PNPM Mandiri Perkotaan adalah terbentuknya lembaga masyarakat yaitu BKM dan KSM. Berdasarkan data dari Kantor Pemberdayaan Masyarakat di Kelurahan Perwira telah terbentuk lembaga masyarakat 100\%. 


\section{Proses}

\section{a. Perencanaan}

Sosialisasi dilakukan untuk memberikan pemahaman kepada masyarakat tentang tujuan, prinsipprinsip pembangunan berbasis masyarakat dan upaya-upaya penanggulangan kemiskinan melalui siklus-siklus pemberdayaan yang telah dirancang dalam program PNPM Mandiri Perkotaan. Sosialisasi program pemberdayaan ekonomi melalui pinjaman bergulir dilakukan oleh Kelurahan selaku pimpinan pemerintahan di tingkat kelurahan memfasilitasi dilaksanakannya PNPM Mandiri Perkotaan. Disamping itu sosialisasi juga dilakukan oleh fasilitator di basis masyarakat seperti di RT, RW, PKK, Posyandu.

Berdasarkan hasil wawancara dengan BKM dan KSM, masih ada sebagian masyarakat menganggap bahwa pinjaman bergulir yang mereka terima bersifat bantuan sepertihalnya Bantuan Langsung Tunai yang pernah mereka terima. Berdasarkan kondisi tersebut menunjukkan pemahaman masyarakat terhadap pinjaman bergulir masih beragam sehingga ada sebagian masyarakat beranggapan pinjaman yang mereka terima tidak perlu dikembalikan.

Selanjutnya

disusun

Perencanaan Jangka Menengah Program

Penanggulangan
Kemiskinan (PJM Pronangkis). Perencanaan jangka menengah (3 tahun) yang disusun sendiri oleh masyarakat dalam bentuk Perencanaan Jangka Menengah Program Penanggulangan Kemiskinan (PJM Pronangkis). Perencaaan tersebut berisi program kegiatan untuk mengembangkan program penanggulangan kemiskinan berdasarkan masalah, hambatan, potensi dan kebutuhan nyata masyarakat.

PJM Pronangkis ini kemudian dijabarkan dalam perencaan siklus tahunan kegiatan penganggulangan kemiskinan. Program dan kegiatan disusun berdasarkan aspirasi masyarakat berdasarkan hasil refleksi kemiskinan dan hasil pemetaan swadaya yang telah dilakukan.Proses penyusunan PJM Pronangkis di Kelurahan Perwira sudah dilaksanakan secara partisipatif melalui sembilan rangakaian kegiatan sosialisasi tentang PJM Pronangkis, sosialisasi lanjutan dan pembentukan tim PJM Pronangkis, bimbingan teknis, lokakarya tingkat kelurahan/desa, penyusunan draft program kerja, penyempurnaan, sosialisasi program, dan bazar PJM Pronangkis. BKM Kelurahan Perwira memiliki kategori BKM berdaya sehingga partisipasi masyarakat pada saat penyusunan PJM Pronangkis lebih 
dari $40 \%$. Dengan demikian partisipasi masyarakat memenuhi persyaratan yang telah ditetapkan minimal $40 \%$.

\section{b. Pengembangan Kapasitas}

Pengembangan kapasitas masyarakat yang telah dilaksanakan dalam PNPM Mandiri Perkotaan di Kelurahan Perwira meliputi: coaching refleksi kemiskinan, pelatihan dasar relawan, coaching pemetaan swadaya, pelatihan/ OJT, keterampilan teknis lainnya, pelatihan BKM, pelatihan dasar, pelatihan madya, pelatihan utama, pelatihan UPK, pelatihan UPS, pelatihan UPL, Makro (kebijakan \& sistem), coaching penyusunan PJM Pronangkis, pelatihan Kades, pelatihan pembuatan media warga, pelatihan manajemen penanggulangan bencana, pelatihan pengembangan data dan informasi komunitas, pelatihan forum BKM, pelatihan dan lokakarya tematik kabupaten.

Berdasarkan hasil wawancara dengan BKM dan KSM, pelatihan yang memberikan keterampilan pada anggota KSM masih sangat kurang. Pemberian keterampilan pada anggota KSM diharapkan dapat meningkatkan pendapatan keluarga melalui usaha rumah tangga.

\section{c. Kinerja Pengelola}

Pengelolaan pemberdayaan ekonomi PNPM Mandiri Perkotaan dilakukan oleh BKM. Kinerja BKM sesuai digariskan dalam AD/ART BKM, meliputi keaktifan anggota, agenda pertemuan rutin, kelengkapan struktur organisasi BKM, dan keterlibatan relawan; Penerapan transparansi, akuntabilitas dan demokrasi Penilaian capaian target indikator kinerja pelaksanaan PNPM MandiriPerkotaan sesuai digariskan dalam pedoman.

Berdasarkan data yang diperoleh BKM Kelurahan Perwira masuk pada kategori BKM Berdaya yang berarti sudah memenuhi kriteria indikator keberhasilan yang ditetapkan. Namun terdapat satu komponen yang masih kurang adalah kemitraan. BKM Kelurahan Perwira belum menjalin kemitraan dengan pihak eksternal, seperti dengan perbankan, perusahaan, atau perguruan tinggi. Dengan program kemitraan akan sangat membantu sebuah BKM dalam mendukung keterlaksanaan sebuah program, seperti memperluas sumber pendanaan, pendampingan, dan pelatihan.

\section{Produk}

Tujuan umum PNPM telah ditetapkan di Pedoman Umum PNPM yaitu Meningkatnya kesejahteraan 
dan kesempatan kerja masyarakat miskin secara mandiri. Melalui pemberian pinjaman bergulir dalam PNPM Mandiri Perkotaan bertujuan untuk menyediakan akses layanan keuangan kepada rumah tangga miskin untuk memperbaiki kondisi ekonomi mereka dan membelajarkan mereka dalam mengelola pinjaman dan menggunakannya secara baik dan benar. Peran PNPM hanya membangun dasar-dasar solusi yang berkelanjutan untuk jasa pinjaman dan non pinjaman di tingkat kelurahan. Sasaran utama pelaksanaan kegiatan pinjaman bergulir adalah rumah tangga miskin (berpendapatan rendah) di wilayah kelurahan/desa. Indikator keberhasilan pemberian pinajaman bergulir adalah Tingkat Pengembalian ekonomi bergulir (Rapayment Rate) min 90\%; Jumlah peminjam yang menunggak $\geq 3$ bulan (Loans at Risk) maksimum 20\%; Rasio pendapatan biaya (Cost Coverage Ratio) > 100; Hasil Investasi (Return on Investment) > $0 \%$.

Program pemberdayaan ekonomi di BKM Kelurahan Perwira pada kondisi memuaskan. Hal ini dapat dilihat dari pencapaian tingkat pengembalian ekonomi bergulir (Rapayment Rate) 93\%; Jumlah peminjam yang menunggak $\geq 3$ bulan (Loans at Risk) sebesar 2,63\%; Rasio pendapatan biaya (Cost Coverage Ratio) sebesar 211,36\%; Hasil Investasi (Return on Investment) sebesar 6,54\%.

\section{KESIMPULAN, IMPLIKASI DAN SARAN \\ Kesimpulan}

Berdasarkan hasil-hasil

penelitian dan pembahasannya, dapat diambil kesimpulankesimpulan sebagai berikut:

1. Evaluasi Konteks

Aspek kebijakan ini telah memenuhi kriteria keberhasilan, yakni PNPM Madiri adalah program nasional dalam wujud kerangka kebijakan sebagai dasar dan acuan pelaksanaan program-program penanggulangan kemiskinan berbasis pemberdayaan masyarakat. Dasar hukum pelaksanaan PNPM Mandiri Perkotaan adalah sama dan merujuk pada Dasar Hukum PNPM Mandiri, sebagaimana ditetapkan dalam Pedoman Umum PNPM Mandiri, Peraturan Presiden Nomor: 13 Tahun 2009 tentang Koordinasi Penanggulangan Kemiskinan. Berdasarkan visi, misi dan tujuan umum PNPM jelas mendukung dalam meningkatkan kesejahteraan dan kesempatan kerja masyarakat miskin secara mandiri yang pada akhirnya dapat mengentaskan kemiskinan. 
Kebutuhan masyarakat akan akses permodalan untuk usaha produktif, dapat dipenuhi melalui pinjaman bergulir. Sasaran Program Pemberdayaan Ekonomi PNPM Mandiri Perkotaan adalah masyarakat miskin. Jumlah keluarga miskin di Kelurahan Perwira Kecamatan Bekasi Utara yang mendapatkan pinjaman bergulir sebanyak 69 KSM dengan jumlah anggota 249 orang. Dari jumlah tersebut yang mendapatkan pinjaman bergulir P2KP sebanyak 65 KSM dengan jumlah anggota 218 orang dan sisanya 4 KSM dengan 31 orang anggota mendapatkan pinjaman bergulir dari PNPM Mandiri Perkotaan. Berdasarkan data dari BKM seluruh masyarakat miskin di Kelurahan Perwira mendapatkan pinjaman bergulir. Indikator yang dijadikan dasar dalam menentukan siapa berhak mendapatkan pinjaman bergulir belum baku hanya berdasarkan perkiraan.

\section{Evaluasi Input}

Tingkat keberhasilan penyediaan sarana dan prasarana kerja BKM adalah sebesar 42,85\%, yaitu dalam kategori sedang. Pola rekrutmen pengelola BKM sudah sesuai dengan prosedur yang telah ditetapkan dalam pedoman pelaksanaan PNPM Mandiri Perkotaan. Selanjutnya lembaga masyarakat sudah terbentuk100 persen.

\section{Evaluasi Proses}

Sosialisasi program pemberdayaan ekonomi melalui pinjaman bergulir dilakukan oleh Kelurahan selaku pimpinan pemerintahan di tingkat kelurahan memfasilitasi dilaksanakannya PNPM Mandiri Perkotaan. Disamping itu sosialisasi juga dilakukan oleh fasilitator di basis masyarakat seperti di RT, RW, PKK, Posyandu. Pemahaman masyarakat terhadap pinjaman bergulir masih beragam sehingga ada sebagian masyarakat beranggapan pinjaman yang mereka terima tidak perlu dikembalikan.

Perencanaan

Jangka Menengah Program Penanggulangan Kemiskinan (PJM Pronangkis). Perencanaan jangka menengah (3 tahun) yang disusun sendiri oleh masyarakat dalam bentuk Perencanaan Jangka Menengah Program Penanggulangan Kemiskinan (PJM Pronangkis) Partisipasi masyarakat pada saat penyusunan PJM Pronangkis sangat lebih dari $40 \%$. Dengan demikian partisipasi masyarakat memenuhi persyaratan yang telah ditetapkan minimal $40 \%$. Pelatihan yang memberikan keterampilan pada anggota KSM masih sangat kurang. Pemberian 
keterampilan pada anggota KSM diharapkan dapat meningkatkan pendapatan keluarga melalui usaha rumah tangga.

BKM Kelurahan Perwira masuk pada kategori BKM Berdaya yang berarti sudah memenuhi kriteria indikator keberhasilan yang ditetapkan, yaitu mendapatkan predikat BKM Berdaya. Kelemahannya BKM Kelurahan Perwira belum menjalin kemitraan dengan pihak eksternal, seperti dengan perbankan, perusahaan, atau perguruan tinggi.

\section{Evaluasi Produk}

Program pemberdayaan ekonomi di BKM Kelurahan Perwira pada kondisi memuaskan. Hal ini dapat dilihat dari pencapaian tingkat pengembalian ekonomi bergulir (Rapayment Rate) 93\%; Jumlah peminjam yang menunggak $\geq 3$ bulan (Loans at Risk) sebesar 2,63\%; Rasio pendapatan biaya (Cost Coverage Ratio) sebesar 211,36\%; Hasil Investasi (Return on Investment) sebesar 6,54\%.

\section{Implikasi}

Bertolak dari kesimpulankesimpulan di atas, terdapat implikasi-implikasi sebagai berikut:

3. Peraturan Presiden Nomor: 13 Tahun 2009 tentang Koordinasi Penanggulangan Kemiskinan menjadi dasar PNPM Mandiri Perkotaan

4. Program pemberdayaan ekonomi melalui pinjaman bergulir membantu masyarakat miskin dalam mengakses permodalan untuk usaha produktif.

5. Peningkatan sarana prasarana pengelola sangat diperlukan untuk meningkatkan pelayanan di masa yang akan datang.

6. Sosialisasi dan pendampingan kepada masyarakat sangat dibutuhkan masyarakat dalam pengelolaan pinjaman bergulir yang diterima sehingga dapat memperkecil tingkat kemacetan dan meningkatkan kemandirian masyarakat.

7. Pemberian pelatihan keterampilan sangat dibutuhkan masyarakat miskin untuk membantu meningkatkan penghasilan

8. Kemitraan dapat membantu dalam peningkatan pemberdayaan masyarakat

\section{Saran}

Berdasarkan kesimpulankesimpulan dan implikasi-implikasi di muka, disampaikan saran-saran sebagai berikut:

9. Umum

Program pemberdayaan ekonomi PNPM Mandiri Perkotaan dapat lebih memperbaiki tingkat 
pendapatan masyarakat miskin harus dibarengi dengan peningkatan akses permodalan dan keterampilan masyarakat miskin.

10. Khusus

a. Kepada Pemerintah Daerah dan BKM, Pertama, hendaknya sarana dan prasarana kerja pengelola BKM dilengkapi sesuai dengan kebutuhan kerja untuk meningkatkan kualitas pelayanan pada masyarakat. Kedua, sebaiknya akses permodalan dapat ditingkatkan melalui program kemitraan. Ketiga, adanya pelatihan yang dapat meningkatkan keterampilan masyarakat dalam upaya meningkatkan penghasilan keluarga.

b. Kepada peneliti lain, agar dilakukan evaluasi terhadap PNPM Mandiri Perkotaan secara lebih luas dengan menganalisis aspek fisik/lingkungan dan aspek sosial.

\section{DAFTAR PUSTAKA}

Arikunto, Suharsimi. dan Cepi Safrudin Abdul Jabar. 2010. Evaluasi Program Pendidikan: Pedoman Teoritis dan Praktis bagi Mahasiswa dan Praktisi Pendidikan, Edisi kedua. Jakarta, Bumi Aksara,
Darmawan, Indra.

(http://indrasetiawanusd.wordpress.com/2006/12/02/)

Esterberg, Kristin G. 2002. Qualitative Methods in Social Research (New York: McGraw Hill,), dikutip secara langsung oleh Sugiyono, 2008. Memahami Penelitian Kualitatif. Bandung:

Alfabeta,

Fitzpatrick, Jody L. James R. Sanders, and Blaine $\mathrm{R}$. Worthen, 2004. Program Evaluation: Alternative Approaches and Practical Guidelines. Boston: Pearson Education, Inc.,

Kementerian Pekerjaan Umum. 2010. Pedoman Pelaksanaan PNPM Mandiri Perkotaan: Bersama Membangun Kemandirian dalam Pengembangan Lingkungan Permukiman yang Berkelanjutan. Jakarta:

Direktorat Cipta Karya, Kuncoro, Mudrajad. 2000. Ekonomi Pembangunan:

Masalah dan Kebijakan.

Yogyakarta: Akademi

Manajemen Perusahaan YKPN,

Owen, John. M. 1993. Program Evaluation, form and Approaches. Boston: Allen \& Unwim, 
Rahardjo, M. Dawam. 2006. Menuju Indonesia Sejahtera. Jakarta: Khanata, Pustaka LP3ES Indonesia,

Sudjana, Djudju. 2006. Evaluasi Program Pendidikan Luar Sekolah. Bandung: Program Pascasarjana Universitas Pendidikan Indonesia dan Remaja Rosdakarya,

Sugiyono, 2008. Memahami Penelitian Kualitatif, Dilengkapi Contoh Proposal dan Laporan Penelitian. Bandung: Alfabeta,

Sugiyono, 2006. Metode Penelitian Pendidikan: Pendekatan Kuantitatif, Kualitatif, dan $R \& D$. Bandung: Alfabeta, Suharto, Edi. 2010. Membangun Masyarakat Memberdayakan
Rakyat: Kajian Strategis Pembangunan Kesejahteraan Sosial dan Pekerjaan Sosial. Bandung: Refika Aditama, Sumarga, Prima. "Analisis Penyebab Kemiskinan Di Indonesia", Jurnal Ekonomi Pembangunan, Vol. 2 No. 2, Maret 2001

Sumaryadi, I Nyoman. 2005. Perencanaan Pembangunan Daerah Otonom dan Pemberdayaan Masyarakat. Jakarta: Penerbit Citra Utama,

Widoyoko, S. Eko Putro. 2011. Evaluasi Program Pembelajaran: Panduan Praktis bagi Pendidik dan Calon Pendidik. Yogyakarta: Pustaka Pelajar. 